\title{
TITLE:
}

\section{A New Host of Eugymnanthea japonica (Leptomedusae, Eirenidae) in Japan}

$\operatorname{AUTHOR}(S)$ :

Kubota, Shin

\section{CITATION:}

Kubota, Shin. A New Host of Eugymnanthea japonica (Leptomedusae, Eirenidae) in Japan. PUBLICATIONS OF THE SETO MARINE BIOLOGICAL LABORATORY 1993, 36(1-2): 9394

\section{ISSUE DATE:}

1993-03-30

URL:

http://hdl.handle.net/2433/176218

RIGHT: 


\title{
A New Host of Eugymnanthea japonica (Leptomedusae, Eirenidae) in Japan
}

\author{
SHIN Kubota \\ Seto Marine Biological Laboratory, Kyoto University, \\ Shirahama, Wakayama 649-22, Japan
}

With Table 1

\begin{abstract}
As the fifth host species of the commensal hydroid Eugymnanthea japonica, a mytilid bivalve, Septifer virgatus, was recorded at Tsushima Island, Nagasaki Prefecture, southern Japan. The attachment sites of the hydroids and their incidence of medusa bud production were observed in this new host.
\end{abstract}

Key words: commensal hydroid, Eugymnanthea japonica, Septifer virgatus, attachment site

The hydroid Eugymnanthea japonica Kubota, 1979 has been recorded from various localities from central to southern Japan, being commensal with four bivalve species, Mytilus edulis galloprovincialis Lamarck, Crassostrea gigas (Thunberg), Barbatia virescens (Reeve), and Chlamys farreri (Jones and Preston) (Kubota, 1992). Recently, I have found this hydroid species associated with the mytilid bivalve Septifer virgatus (Wiegmann) for the first time.

Host. The hydroid occurred in one specimen of Septifer virgatus that measured 46 $\mathrm{mm}$ along the anterior-posterior axis, and which was collected by the author intertidally at Takeshiki in Asou Bay, Tsushima Island, Nagasaki Prefecture on August 21, 1992. S. virgatus was rare at this locality, and only 22 other specimens were collected there on August 20-22, 1992. These specimens were smaller than the host specimen, i.e. at least $24 \mathrm{~mm}$ along the anterior-posterior axis, and had no bivalveinhabiting hydroids of any species in their mantle cavities.

Attachment site of hydroid. A total of 84 hydroids were found in the mantle cavity, attached only to the posterior part of the mantle. Nearly the same number of zooids were found on each side of the host (Table 1).

Table 1. The number of hydroids of Eug.ymnanthea japonica in mantle cavity on each side of an infected Septifer virgatus from Takeshiki, Tsushima Island.

\begin{tabular}{lccc}
\hline \hline $\begin{array}{l}\text { Mantle } \\
\text { cavity }\end{array}$ & $\begin{array}{l}\text { No. of hydroids } \\
\text { with fully developed } \\
\text { medusa buds }\end{array}$ & $\begin{array}{l}\text { No. of hydroids } \\
\text { with small medusa buds }\end{array}$ & $\begin{array}{l}\text { No. of hydroids } \\
\text { without medusa buds }\end{array}$ \\
\hline Left & 1 & 13 & 30 \\
Right & 1 & 8 & 31 \\
\hline
\end{tabular}

Publ. Seto Mar. Biol. Lab., 36(1/2), 93-94, 1993. (Article 7) 
Hydroid. Most of the hydroids within the host were small. The incidence of medusa bud production was $27.4 \%$. The precise identification of the hydroids was possible in only two large specimens with fully developed medusa buds. Daughter hydroids were not found in any of these hydroid specimens.

Remarks. The small number of small hydroids attached to a restricted part of the body of the present new host suggests that infection by a Eugymnanthea colony in this host specimen is probably recent. Septifer virgatus is also used rarely as a host of another bivalve-inhabiting hydroid, Eutima japonica Uchida; this association has been recorded only at Oshoro, Hokkaido, and at Otsuchi, Iwate Prefecture, in northern Japan (see Kubota, 1992). Although Eutima japonica occurred associated with $M y$ tilus edulis galloprovincialis and Barbatia virescens at the present collecting site (Kubota, 1992; present study), it was not found within S. virgatus, as described above.

\section{Acknowledgements}

This study was supported by a grant-in-aid for scientific research from the Showa Seitoku Kinen Zaidan.

\section{References}

Kubota, S. 1992. Four bivalve-inhabiting hydrozoans in Japan differing in range and host preference. Sci. Mar., 56(2-3): 149-159. 